DOI: $10.30525 / 978-9934-588-61-7-12$

\author{
Radionov Yu. D. \\ Doctor of Economic Sciences, Head of the Department \\ of International Standards Adaptation and Implementation \\ Accounting Chamber of Ukraine
}

\title{
THE ROLE OF BUDGET EXPENDITURES IN REGULATING THE SOCIO-ECONOMIC DEVELOPMENT OF THE COUNTRY
}

\section{Summary}

Theoretical and methodological principles of budget regulation of the socio-economic development of the country are revealed. The economic essence of budget expenditures is determined. The functions of the country and their role in the formation of budget expenditures are analyzed. The state of reforming local self-government bodies in order to increase the share of budget expenditures in the structure of local budgets is studied. The dynamics of the consolidated budget of Ukraine and the experience of countries with developed and transformational economies in directing the share of budget expenditures to meet public needs are analyzed. Examples that reveal the current problems of efficient and effective use of budget funds in Ukraine are given. Emphasis is placed on the need to optimize the structure of expenditures and the application of program-target method to improve the efficiency of budget funds. Measures to improve the mechanism of regulation of budget expenditures are proposed and priority areas for their use in the system of the socio-economic development of the country for the medium term are identified.

\section{Introduction}

In the system of budgetary regulation of the socio-economic relations, the leading role belongs to financial instruments related to the use of budget expenditures to regulate the socio-economic processes in society, which are directly implemented in the targeted impact of budgetary relations on virtually all aspects of society.

The country, performing its functions, redistributes financial resources, creating conditions to ensure the proper standard of living necessary for its reproduction and development, guaranteeing equality of personal freedom, protection of the individual from negative environmental and social impact. 
There is still a lack of comprehensive research in the economic literature, in particular the role of budget expenditures in regulating the socio-economic development of the country. Meanwhile, budget expenditures in modern conditions of development remain an important tool for implementing both budget and financial policies of the country, aimed primarily at improving the welfare of citizens. In the process of implementing fiscal policy, budget expenditures play an important role in solving the problems of the socioeconomic development of the country. The rate of economic growth, the development of social infrastructure, and the degree of modernization of medical, educational, and social services depend on the efficiency of their regulation and the effectiveness of moving significant amounts of money from one direction to another.

Effective regulation of budget expenditures accelerates the processes of the socio-economic development of the state, affects the quality of structural changes in the economy, increases the effectiveness of fiscal policy, ensures the stability of the country's financial system.

Improving the mechanism for regulating budget expenditures is an important factor in accelerating economic transformation, ensuring the irreversibility of institutional changes in the financial and budgetary system of the country, serves as a tool to ensure efficient use of natural and economic resources, taking into account cyclical economic development.

The ability to regulate the socio-economic processes in order to increase the welfare of people, protect the most vulnerable groups, increase the income of public sector employees, ensure the proper functioning of such areas as health, education, culture, etc. depends on the amount of budget expenditures.

Such foreign and domestic scientists as J. Keynes, P. Krugman, P. Samuelson, J. Stiglitz [1-4], V. Bazylevych [7], O. Vasylyk [6], P. Leonenko [14], K. Pavliuk [5; 17], I. Chuhunov [8; 9] etc., made a significant contribution to the study of the role and essence of the impact of budget expenditures on the system of regulation of socio-economic development. At the same time, in the current conditions, it is important to strengthen the regulatory role of budget expenditures as a tool for economic growth, taking into account the financial capabilities of the budget, economical and efficient use of budget funds in priority areas of socioeconomic development of Ukraine.

The purpose of the study is to reveal the role and essence of the theoretical and methodological foundations of budget expenditures, improving the mechanism of their regulation in the system of the socio-economic development of Ukraine in modern conditions of economic transformation.

This necessitates a theoretical and methodological generalization and some rethinking of the accumulated views of science on budget expenditures as a tool of the socio-economic regulation, as well as determining their role in the development of Ukraine in the current conditions. 


\section{Part 1. Theoretical and methodological principles of the essence of budget expenditures}

A well-known English economist J.M. Keynes raised the issue of market economy instability in the scientific work «General theory of employment, interest and money» [1]. He proved that without government intervention, a market economy cannot develop stably. Instead, the effective functioning of the country requires significant financial resources, for which the country accumulates and redistributes gross national product in cash. In many developed countries, budget expenditures are growing rapidly, outpacing the growth rate of national product. This is due to the expansion and complication of functions of the country, which increases the role of budget expenditures in regulating socio-economic development.

In the scientific and economic literature, there are different approaches of scientists to determine the role and essence of budget expenditures in the system of regulation of the socio-economic development of the country, taking into account their main components. Most scholars believe that the regulation of budget expenditures is an important tool for the implementation of national economic policy aimed at meeting the important socio-economic needs of society.

The tool for regulating budget expenditures provides for various forms of influence on social processes and is determined by the need to strengthen the effectiveness of the budget mechanism, increase its efficiency and effectiveness in the implementation of budget policy priorities. The opportunities of all levels of budgets that are part of the structure of the budget system of the country are used to solve the problems of improving the productive forces, transformation of financial and economic and other social institutions, development of the social sphere. This indicates the need to establish the role and essence of the regulation of budget expenditures to determine the priority areas for improving this mechanism in the context of national, regulatory policy pursued by the government in the interests of meeting public needs. In their research, most scholars do not separate budget expenditures from the budget as a whole. For example, K.V. Pavliuk notes that the regulatory impact of the budget on the economy depends primarily on the size of the centralized fund of the government funds. The level of centralization of financial resources is influenced by various factors: the level of the socio-economic development, methods of managing social production, priorities, goals and objectives of the socio-economic development, the scale of structural changes in economic proportions and so on [5, p. 54].

O.D. Vasylyk believes that the budget is the main tool of the government regulation of the socio-economic processes in market conditions. The formation of revenue and expenditure parts of the budget is associated with the main macro indicators of the socio-economic development of the country for the year [6, p. 160-161]. 
V.D. Bazylevych notes that budget regulation is an annual redistribution of national centralized financial resources between different parts of the budget system in order to balance budgets at the level necessary for local authorities to perform their functions [7, p. 39].

The essence of regulating budget expenditures in the system of the socioeconomic development is carried out within the opportunities established in the country for distribution and redistribution of financial resources within the budget system, established relations between all participants in the budget process in the formation and implementation of fiscal policy to influence cyclical economic development, employment, ensuring economic growth, improving the welfare of the population.

Budget expenditures are an important component of national expenditures. They are the expression of economic relations that arise when the state uses budget funds.

Budget expenditures are the indicator of the socio-economic policy of the country. The economic essence of the formation of budget expenditures is the need to solve complex problems that arise in the economic life of the country. With the help of budget expenditures, the country performs its functions and regulates the socio-economic processes.

According to professor I. Chuhunov, the main regulatory role of budget expenditures is the redistribution of gross domestic product (GDP) between areas of economic activity, administrative units of the country, social groups to ensure the effectiveness of the socio-economic development. Budget expenditures in economic essence are the tool for the distribution and redistribution of the centralized monetary fund of the state and its use for its intended purpose for the growth of public welfare [8, p. 220].

The nature and content of budget expenditures in the system of regulation of the socio-economic development is to perform the basic functions assigned by society to the state.

In our opinion, the functions of the country are a reflection of its state of development, a demonstration of socio-economic priorities that the country seeks to achieve using appropriate levers and mechanisms to influence the economy, including through budget expenditures.

Analyzing the formation of state functions and the need for budget expenditures in historical terms, it should be noted that among scholars who attributed the key role of the country in economic life, including the formation of budget expenditures, the works of Jean-Baptiste Colbert (1619-1683, France, the 17th century) with his concept of «state-entrepreneur» are known. It was at the initiative of J. Colbert, with the help of budget expenditures in France, there began to create the first manufactories, arsenal, postal service, organized large projects and entered the markets of other countries.

In addition to the theoretical justification of the importance of budget expenditures and government intervention and regulation of the national economy, an important place in the system of values and the role of the 
country in regulating economic activity depends on the mindset and national characteristics of the people, culture, customs and traditions.

There are examples in history where the country has exerted little or no pressure on the economy, using powerful levers of influence, for example, through budget expenditures, the mechanism of stimulating priority industries or other management methods. In particular, a strong government influence on the economy is inherent in a country like Russia, where, as then and now, we see strong positions of a government influence on business development and entrepreneurship through the system: subsidies, grants, benefits, loans, taxes, etc.

The mechanism of regulation of budget expenditures is an important component of the development of public institutions. Improving the quality of regulation of budget expenditures will significantly increase the effectiveness of fiscal policy, strengthen the country's financial system, ensure institutional transformation within the entire economic space. The effectiveness of the regulation of budget expenditures depends on the level of development of financial and economic institutions, the proper interaction of participants in the budget process in the regulation of economic and social processes.

The quality of regulatory processes directly proportionally affects the formation of the optimal structure of the budget and financial systems of the country.

The purpose of regulating budget expenditures in the system of the socioeconomic development of the country is the implementation of its balanced economic policy. The regulatory function of budget expenditures is a component of financial regulation, and the effectiveness of regulatory processes requires constant improvement of all elements within the budget system, because it depends on the completeness of the tasks assigned to the country in implementing budget policy. Effective implementation of measures, programs of budgetary policy forms the basis of stability of the financial system of the country. In this context, the interconnection of all levels of budgets aimed at fulfilling the tasks of the socio-economic development of territorial and administrative units, ensuring sustainable national macroeconomic stabilization is important.

Improving the efficiency of budget regulation depends on the degree of understanding of the economic essence of this regulatory system and the main factors that determine its development $[9$, p. 8].

Excessive concentration of budget funds in the central government was a powerful challenge for the budget system, which has existed in Ukraine until recently, bleeding the initiative and desire of territorial communities to solve urgent problems of the socio-economic development. The Concept of local self-government reform and territorial organization of power in Ukraine adopted by the Cabinet of Ministers of Ukraine No 333-r dated April 1, 2014 states that the system of local self-government does not meet the needs of society [10]. It is the inability to meet the needs of the community that has 
justified the need for local government reform, which has actually begun in Ukraine in 2015.

The main purpose of decentralization is the transfer of powers and finances from the state authorities as close as possible to the people, i.e., to the local governments.

As of January 10, 2020, 1029 amalgamated territorial communities have already been created in Ukraine [11] and this process is ongoing. The pace of creation of the amalgamated territorial communities differs significantly in terms of oblasts, in some regions, the reform is proceeding rapidly, in others, on the contrary, it is slowing down.

This situation is explained both by objective reasons (area of the region, number of inhabitants, number of settlements, etc.) and subjective (lack of objective information about the unification process, non-acceptance of changes by the population, concern for the educational and medical institutions, unwillingness of financially prosperous communities to amalgamate with the depressed areas, etc.) [12, p. 262].

According to the rating of oblasts, in which affluent communities are formed, Zhytomyr, Dnipropetrovsk, Chernihiv, Khmelnytskyi, Zaporizhzhia oblasts are in the lead [11].

In this context, in our opinion, when creating the amalgamated territorial community, it is not the number of the amalgamated territorial communities that is important, but their quality, it is extremely important not to allow formalism and to take into account the economic component, which will determine the amount of budget revenues, and the formation of the appropriate level of budget expenditures necessary for the regulation of socioeconomic development of the territories, which will certainly have a positive impact on improving the level and quality of life of citizens.

In the current conditions, it is important to adhere to the principle of financial sufficiency of local budgets, reduce management costs, improve the quality of decision-making at the local level, the effectiveness of the use of funds in the implementation of regional programs of the socio-economic development.

The country's commitments to the socio-economic development require balanced, guided steps, including the consolidation of budget expenditures in the most important, strategic areas of the socio-economic development. It is necessary to form an appropriate institutional environment, where there is tangible support of financial and budgetary institutions in the implementation of budget programs aimed at the socio-economic development of territories, reducing the budget deficit, forming a medium-term strategy for the socioeconomic development.

Improving institutional mechanisms of regulation will have a positive impact on the budget process, the level of validity of budget indicators, highquality revenue, the formation of appropriate budget expenditures, areas of use of funds and implementation of budget programs. 
One of the ways to improve both budget and financial policy in the system of regulation of the socio-economic development of the country is:

- stability of fiscal policy, improvement of the administration system, refusal to introduce new types of taxes, reduction of the tax burden on business entities;

- optimization of the structure of budget expenditures by reducing unpromising and outdated budget programs;

- completion of local government reform by delegating a significant share of powers and the appropriate amount of financial resources to the united territorial communities, thereby changing the structure of the budget system and increasing the share of budget expenditures in local budgets;

- completion of the reform of the social security system, in particular the monetization of social benefits;

- strengthening the management of the budget deficit, linking it with the cyclical economic development of the country.

The main task of forming an effective mechanism for regulating budget expenditures in the system of socio-economic development is to create appropriate conditions to stimulate the development of basic high-tech industries, which in the future may form the basis of a new Ukrainian economy.

The degree of development of the domestic economy depends on the effectiveness of the regulatory mechanism of economic policy, the level of financial infrastructure, institutional and competitive economic environment, investment structure, employment, the share of innovation in the overall structure of social production.

The role of the country as a public institution and the share of budget expenditures in state innovation and investment activities is important, in particular: modernization of such budget-generating industries as: agroindustrial complex, processing industry, mining, IT sector development, road infrastructure, transport services, nanotechnology and others economic industries with a high share of value added.

Increasing investment activity among economic entities, including through budget funds, provides an increase in the efficiency of capital investments, which will promote economic growth, improve the effectiveness of structural changes in the economy. The introduction of tax holidays for businesses, a significant factor in stimulating economic transformation, maintaining sustainable, positive dynamics of domestic production, building capacity for economic growth and prosperity.

Budget expenditures, as a component of budget policy, are the important tool for ensuring the socio-economic development of the country aimed at solving its priorities, stimulating domestic demand, intensifying business activity, reducing unemployment.

In modern conditions, the impact of the regulation of budget expenditures on the processes of economic reproduction, the formation of the basis for 
further economic transformation. It is necessary to reduce the level of public debt, instead of forming the optimal structure of budget expenditures to ensure appropriate economic growth, increase the revenue side of the budget and the corresponding budget expenditures to address the socio-economic development of the country.

Budget expenditures play a leading role in providing financial resources to domestic businesses, especially during the crisis and their limited access to external credit resources. In this situation, economic growth is stimulated, the financial and economic condition of the country is stabilized.

Budget expenditures are the tool for attracting investment through the implementation of long-term strategy of the socio-economic development of the country. Budget investments in the economy can increase the welfare of citizens, improve the economic and social situation in the country, reduce internal risks, stabilize inflation, change the expectations of economic entities.

In addition to sectors of economic activity, budget expenditures provide financial resources to territorial and administrative units, which is reflected in the appropriate proportions in the distribution of GDP.

In the chain of budgetary relations, the expenditures of the consolidated budget of Ukraine have an important place as a statistical aggregate indicator that determines the use of centralized and decentralized funds.

The consolidated budget of Ukraine characterizes the generalized statistical indicator of expenditures of state and local budgets, gives an idea of budget policy and priority areas of use of budget expenditures.

The structure of expenditures of the consolidated budget of Ukraine according to the functional classification characterizes the goals of the country. These expenditures demonstrate the multi-vector areas of the socioeconomic development of the country and its priorities (Table 1).

According to the table, there is a steady upward trend in total expenditures by 841619 million UAH, or $62.46 \%$ in 2019 , compared to 2013 . It should be noted that during this period, there was a significant increase in expenditures in almost all areas. Expenditures on national defense increased the most, namely by 989892 million UAH or $85.83 \%$, which is related to hostilities in eastern Ukraine. Expenditures on other sectors of the economy $(82.14 \%)$, transport (73.57\%), and law enforcement agencies (70.69\%) increased significantly.

If we compare the expenditures of the consolidated budget of Ukraine by functional classification in 2019 with the previous 2018, we can see their reduction in utilities by 5226 million UAH (17.23\%), transport 2.619 million UAH, (3.73\%), social protection -4.628 million UAH (3.06\%). 


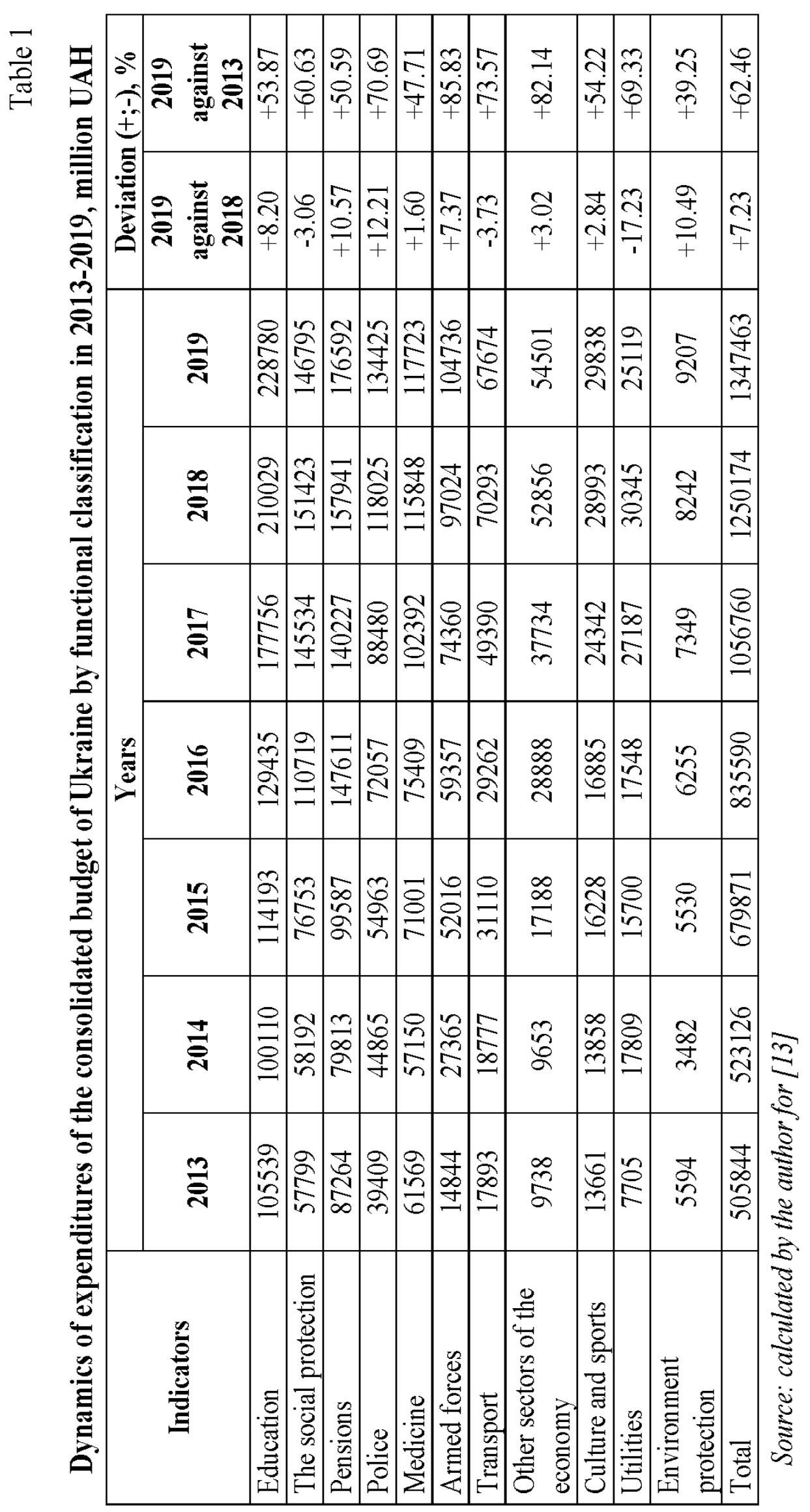


It should be noted that the consolidated budget expenditures are the indicator of statistical information on the peculiarities of the formation of strategic directions for the use of budget expenditures of the country. The functional purpose of budget expenditures follows from the main functions of the state.

The amount of budget expenditures depends on the economic situation in the country and social priorities. The larger the budget and the share of budget expenditures in GDP, the more financial resources are redistributed through it and, accordingly, the volume of public goods and services provided to the population increases. In this situation, the role and degree of regulatory impact of budget expenditures on the economy and social sphere is growing.

\section{Part 2. Problems and prospects of regulation of budget expenditures}

In developed countries, the share of budget expenditures in GDP varies significantly. The difference is justified by the fact that each country solves this problem individually, based on traditions, mentality of the people, socioeconomic conditions.

In countries with developed and transformational economies, where the model of the "welfare state» is widespread, the issue of social protection is one of the priorities where a significant amount of budget expenditures is directed.

The role of the budget, the budget system in the socio-economic model, which is typical of most European countries and which they are trying to introduce in Ukraine, is growing. In Europe, several models are used with different degrees of redistribution of GDP through the budget system: British (the UK, Ireland - insignificant); Scandinavian (Sweden, Denmark - extremely high, in the range of 46-65\%); continental (France, Germany - significant); Mediterranean (Italy, Spain, Portugal - relatively low, 15-30\%). Meanwhile, the purpose and tools of its implementation in these models are essentially the same. The basis of budget decentralization is the principle of fiscal adequacy, according to which the opportunity to strengthen the financial base of all parts of the budget system is realized. In practice, an example of such an approach is the system of the developed European countries [14, p. 119].

In the European countries, the main task of budget expenditures is to stimulate innovation and investment activities and adherence to the principle of balance and sustainability of the budget system.

In the current conditions, it is important not only to increase budget expenditures, but on the contrary to increase their efficiency and effectiveness in accordance with the objectives of fiscal policy, according to the stated guidelines for the socio-economic development of the country.

It is important not to allow inefficient use of budget funds, although, as the results of audits conducted by the Accounting Chamber show, this problem is extremely relevant for Ukraine. Thus, the results of audits conducted in 2019 revealed facts of inefficient management and use of budget funds in the 
amount of 14 billion 684.1 million UAH [15, p. 7]. In the structure of inefficient management and use of budget funds, the largest share falls on inefficient use of funds - 6608.5 million UAH (45\%), inefficient management of funds - 6184.7 million UAH (52.1\%), unproductive use of funds 1360.5 million UAH (9.35), uneconomical use of funds - 530.4 million UAH $(3.6 \%)[15$, p. 10].

Inefficient use of budget funds, unfortunately, is a common practice that slows down the process of the socio-economic development of the country. For example, the results of the audit of the effectiveness of the use of subventions from the state budget to local budgets for financial support of construction, reconstruction, repair and maintenance of public roads of local importance, streets and roads of communal property in settlements, the following. In general, the subvention in the amount of 163.5 million UAH was inefficiently used in Zhytomyr oblast, 22.8 million UAH in Kyiv oblast, 45.7 million UAH in Luhansk oblast, 6.4 million UAH in Mykolaiv oblast, 170.8 million UAH in Poltava oblast, 17 million UAH in Ternopil oblast, 20.9 million UAH in Cherkasy oblast.

At the same time, the facts of causing damage to the state as a result of payment for unperformed repair works (unprovided services) in the total amount of 46.6 million UAH were established; payment for works performed in accordance with the project documentation - 49.5 million UAH; unjustified use of funds for the performance of design and survey works of the future period -35.9 million UAH; payment for the purchase of low-quality design and estimate documentation - 28.9 million UAH; violations in advance payment - 14.4 million UAH; illegal expenses for the maintenance of the customer's service - 7.4 million UAH; non-profit and loss of return asphalt concrete materials - 4.5 million UAH; unjustified payment of procurement and storage costs -0.5 million UAH, etc. [15, p. 171].

Inefficient use of budget expenditures has a negative impact on the socioeconomic condition of the country, including the restoration of road infrastructure, construction of modern schools, kindergartens, hospitals, overhaul of housing and communal services, restoration of architectural monuments, environmental protection, etc.

The efficiency of budget expenditure management should be significantly increased, which means optimizing their share in each area of use in the overall structure of expenditures, the architecture of budget expenditures should ensure the solution of the main tasks of social development.

Budgeting by results should be an important area of improving the architecture of the budget system [14, p. 119]. Because budget expenditures aimed at the implementation of the socio-economic development programs interact with each other, strengthening or, conversely, weakening its effective component

In the formation of budget revenues and corresponding expenditures, it is important to use effective approaches in terms of key components, the 
application of quantitative and qualitative analysis of the impact of budget expenditures at all levels of budgets on the socio-economic development, and the application of program-targeted planning methods funds.

It is the model of program-targeted budgeting that very clearly and in detail outlines all positions of budget services in terms of their quantity and quality $[16$, p. 56].

The introduction of the program-target method of budgeting should be carried out through the mechanism of improving the regulation of budget expenditures, accompanied by the efficiency of public institutions and the implementation of systematic measures of strategic planning.

In our opinion, medium-term planning combined with the program-target method is the methodological tool that strengthens actions to ensure effective management of budget expenditures.

The development of the system of planning and use of budget expenditures on the principles of the program-target method requires the improvement of the budget process, the introduction of medium-term planning, strengthening the focus on the final results and improving the efficiency of budget spending.

Perspective medium-term budget planning based on the main directions of formation and use of budget expenditures, in accordance with the goals and objectives facing the country at the stage of its development, is one of the important tools for regulating the socio-economic development of the state. The main task of this regulation is to ensure the implementation of the objectives of programs of the socio-economic development of administrative and territorial units, but it is important to maintain the necessary margin of stability of the budget system. It is expedient not only to develop forecast indicators for the future, but also to determine a long-term budget strategy taking into account the cyclical development of the economy, which will significantly increase the manageability of the budget process and the effectiveness of budget funds.

The introduction of medium-term budget planning is a prerequisite for a balanced and consistent public policy, will allow to synchronize and coordinate it not only in time (in the short and medium term), but also on regional and sectoral grounds, as well as lead budget programs and resources in line with the socio-economic development priorities, strengthen fiscal discipline and prevent populist political decisions that are not backed by financial resources [17, p. 54].

The main task of budget regulation is to streamline the number of budget programs, integrated assessment of their implementation, drawing up by the main managers of budget funds activity plans for the relevant budget periods, taking into account the prospects of the economy.

Budget expenditures in the system of regulation of socio-economic development should be based on a set of forms, means, mechanisms for the formation and implementation of budget policy objectives. In turn, fiscal 
policy should be based on the strategy of implementing the program of socioeconomic development of the country in the near future.

Given the limited financial resources, an important task is to justify the goals and objectives of the strategy of the socio-economic development of the country, the coordination of financial capabilities of the budget for their implementation within budget periods.

It is expedient in the current conditions of development to improve a systematic approach to the application of forecast financial and economic indicators of budget expenditures in order to assess the impact of various factors (external and internal) on budgetary sustainability, taking into account economic cyclicality. The implementation of forecast indicators of budgetary stability will increase the level of budget adoption with a corresponding deficit, efficiency and effectiveness of the use of budget funds.

In the medium term, an effective way to regulate budget expenditures is to provide financial support to industries that need it to stimulate consumer demand, business activity, maintain a stable level of prices for basic necessities, unify and simplify customs and fiscal administration procedures, ensure openness and transparency in the budget sphere, further improvement of budget expenditure management methods.

In the context of economic transformations, it is important to use budget expenditures as a tool to regulate macroeconomic stabilization and create a positive impact on economic growth. Budget funds should be a significant source of investment, a means of economic transformation, an endogenous factor of economic growth, which will increase the level of social development, sustainable dynamics of the socio-economic indicators and welfare of citizens.

\section{Conclusions}

Budget expenditures are the tool for the implementation of state functions, an integral element of fiscal policy, which play a leading role in the system of the socio-economic development of the country. Their effective and efficient regulation depends on macroeconomic indicators and should adapt the appropriate mechanisms, tools and levers in order to strengthen the processes of the socio-economic transformation, increase the welfare of the population. Development and implementation of an effective mechanism for regulating budget expenditures in the socio-economic development of the country should be based on scientifically sound provisions, including the relationship with the cyclical development of the economy, increasing budget planning, reducing the share of public debt in GDP, optimizing the structure of budget expenditures based on the pace of economic development, the introduction of program-targeted budgeting method, the formation of medium- and long-term budget strategy. The creation of an effective mechanism for regulating budget expenditures should be based on the experience of countries with developed and transformational economies. 
It is expedient to further improve the regulatory function of budget expenditures in the system of the socio-economic development of the country. Strengthening the role of budget expenditures as an instrument of economic growth, a component of budgetary and financial policy in the context of the general concept of social development.

One of the most important issues is to prevent a decline in living standards, especially for the most vulnerable groups. The state must act as a guarantor that the standard of living will not fall below the subsistence level. Given the limited budget, financial resources should be strictly regulated on a system of objective indicators of social norms, state standards and distributed according to the minimum needs and capabilities of society at this stage of the socioeconomic development. Compliance with such requirements will improve the planning of budget expenditures in priority areas, ensure the transition to a new level of budget forecasting, preparation of detailed justifications, coordination of medium-term and current plans for the socio-economic development of the country.

Directions of budget expenditures affect the general state of the socioeconomic development of the country. The transition to a new level of management and regulation of budget expenditures involves optimizing the structure, improving the efficiency of their management and use, which in the current conditions is extremely important for Ukraine. It is necessary to increase the effective indicators of the use of budget expenditures, as well as to direct a significant amount of them to social programs, as the social protection of the population depends on it. It is extremely important to direct budget expenditures to priority areas of the socio-economic development, ensuring the process of radical structural economic transformations in the country. In addition, budget expenditures should be used effectively by all participants in the budget process, which will have a positive impact on the level of the socio-economic development of the country and its financial stability.

\section{References:}

1. Keynes J.M. (1999) Obschaya teoriya zain'atosti, procenta i deneg [The general theory of employment, interest and money]. Moscow: Gelios ARV. (in Russian)

2. Krugman P.R. (2008) The Return of Depression Economics and the Crisis of 2008. WWNorton. (in English)

3. Samuelson Paul E., Nordhouse Wilm. D. (2010). Ekonomika [Economics]. Moscow: Williams. (in Russian)

4. Stiglitz, J., Ocampo, J.A., Spiegel, S. et. al. (2006). Stability with Growth: Macroeconomics, Liberalization and Development. Oxford: Oxford University. (in English).

5. Pavliuk K.V. (2006) Byudget i byudgetniy process v umovah tranzitivnoi ekonomiki Ukraini [Budget and budget process in the transitive economy of Ukraine]: Monograph. Kyiv. (in Ukrainian)

6. Vasylyk O.D. (2003) Teoriya finansiv [Theory of finance]. Kyiv: NIOS. (in Ukrainian) 
7. Bazilevich V.D., Balastrik L.O. (2002) Derzhavni finansi [State finance]. Kyiv: Attica. (in Ukrainian)

8. Chuhunov I.Ya., Ignatiuk I.M. (2016) Formuvan'a vydatkiv byudgetu u sistemi social'no-ekonomichnogo rozvitku krainy [Formation of budget expenditures in the system of socio-economic development of the country]. Economic Bulletin of the University. Pereyaslav-Khmelnytsky State University named after Hryhoriy Skovoroda, vol. 28(1), p. 217-226. (in Ukrainian)

9. Chuhunov I.Ya. (2005) Teoretychni osnovy sistemi byudgetnogo regulyuvan'a [Theoretical foundations of the budget regulation system]. Kyiv. (in Ukrainian)

10. Cabinet of Ministers of Ukraine (2014) Rozporyadzhen'a Kabinetu Ministriv Ukrainy vid 01.04.2014 №333-r «Pro shvalenya koncepcii reformuvan’ya miscevogo samovryaduvan'a ta teritorial'noi organizacii vlady v Ukrainy» [Order of the Cabinet of Ministers of Ukraine dated 01.04.2014 № 333-r «On approval of the Concept of reforming local self-government and territorial organization of power in Ukraine»]. Available at: http://zakon0.rada.gov.ua/laws/ show/333-2014-\%D1\%80 (Accessed 01 June 2020). (in Ukrainian)

11. Cabinet of Ministers of Ukraine. Decentralizatsiya v Ukrainy [Decentralization in Ukraine] Available at: http://www.decentralization.gov.ua (Accessed 05 June 2020). (in Ukrainian)

12. Zaslavska O.I., Ogorodnik O.V. (2017) Finansova detsentralizatsiya v Ukrainy: stan, problem ta perspectivy rozvitku [Financial decentralization in Ukraine: state, problems and prospects of development]. Collection of scientific works of Uzhhorod University, series «Economics», vol. 2(50), p. 261-266. (in Ukrainian)

13. Vidatki. Tsina derzhavy [Expenses. State price]. Available at: http://cost.ua/budget/ expenditure/ (Accessed 05 June 2020). (in Ukrainian)

14. Leonenko P.M., Kuzkin E.Y., Yukhimenko Y.V. (2018) Institucional'ne seredovische byudzhetnoi sistemi [Institutional environment of the budget system] Finance of Ukraine, vol. 5, p. 110-124. (in Ukrainian)

15. Accounting Chamber of Ukraine (2020). Zvit Rahunkovoi palati za 2019 rik [Report of the Accounting Chamber of Ukraine for 2019]. Available at: https://rp.gov.ua/ Activity/Reports/ ?id=876 (Accessed 13 June 2020). (in Ukrainian)

16. Golinska O.V. (2013) Shlyahi ta rezervi vdoskonalen'a sistemi upravlin'a mistsevimy budgetami [Ways and reserves to improve the management system of local budgets]. Odessa. (in Ukrainian)

17. Pavliuk K.V., Shaporenko O.O. (2018) Rozvitok serednyostrokovogo byudgetnogo planuvanya $\mathrm{v}$ Ukrainy [Development of medium-term budget planning in Ukraine] Finance of Ukraine, vol. 9, p. 45-59. (in Ukrainian) 